Journal of Engineering and Applied Sciences 14 (Special Issue 4): 7305-7312, 2019

ISSN: 1816-949X

(C) Medwell Journals, 2019

\title{
Modified Model for Municipal Solid Waste in Simulated Controlled Sanitary and Bioreactor Landfills
}

\author{
${ }^{1}$ Entessar Kareem Hussain and ${ }^{2} \mathrm{Jathwa} \mathrm{Al}$-Ameen \\ ${ }^{1}$ Department of Civil Engineering, College of Engineering, University of Al-Qadisiyah, \\ Al Diwaniyah, Iraq \\ ${ }^{2}$ Department of Environmental Engineering, College of Engineering, University of Baghdad, \\ Baghdad, Iraq \\ entesar_kareem@yahoo.com
}

\begin{abstract}
The degradation of Municipal Solid Waste (MSW) over time and associated settlement is of special importance when estimating additional space, designing temporary and final closure covers of landfills as well as planning vertical expansion of existing facilities. Most settlement models applied to solid waste were developed for inorganic soils or peat. Furthermore, these models were not developed considering all the factors effect on settlement, furthermore they applied to simulate the conventional landfills only. In case of bioreactor landfills, waste settlement will include creep as well as biological components due to the accelerated degradability of waste particles as leachate is recycled. The objective of this study is to present a settlement prediction model which accounts for changes in material characteristics as a function of the waste degradation rate. As biodegradation takes place, the organic solid mass is redused and the void ratio increases with a subsequent increase in waste settlement. In general, published settlement models do not capture these phenomena. The model developed herein is based on the results of an experimental result. Settlement components including primary, creep and biodegradation effects are identified as a function of the state of decomposition. One-dimensional oedometer tests $(50 \mathrm{~mm}$ cell) was performed on shredded refuse in pilot-scale reactors for measurement of compression indices representing primary $\left(\mathrm{C}_{\mathrm{c}}^{*}\right)$, creep $\left(\mathrm{C}_{\mathrm{c}}\right)$ and biological $\left(\mathrm{C}_{\beta}\right)$ on samples ranging from fresh to well-decomposed refuse. The time factors, $t_{1}, t_{2}$ and $t_{3}$ for the compressibility were determined from the long term settlement curve and utilized for model development. The proposed model was verified using the settlement model parameters obtained from laboratory test and comparing predicted settlement with observed field settlement from sanitary and bioreactor simulators landfills.
\end{abstract}

Key words: MSW, vertical, inorganicsoils, biological, biodegradation, bioreactor and fills

\section{INTRODUCTION}

Landfilling is one of the most a common, economic and feasible means of disposing Municipal Solid Waste (MSW), ranging in it is occupation from several to hundreds of acres (Ling et al., 1998). Efficient use of landfill space becomes more significant in the context of urban regions of developing countries where a lack of land space limits the possibility of any new development (Grisolia, 1996). Even though the closed landfill is considered a viable site of land utilization, the performance of any structure built on a landfill will depend to a great extent on the ability to predict the anticipated settlement. Moreover, prediction of settlement contributes to the determination of the useful lifespan of the landfill and assists in the design of its components such as cover and liner systems (El-Fadel and Khoury, 2000).
Traditional soil mechanic models: MSW settles under its own weight and external loads are placed on the landfill. External loads include daily soil cover, additional waste layers, final cover and facilities such as buildings and roads such settlement lasts very long period of time (Zhang and Wang, 2008; Babu et al., 2009).

Settlement of MSW is known to be a function of many factors such as the material, density achieved after compaction of the landfill, the thickness of the cover, MSW composition like moisture and volatiles, climate, self-weight, overburden, method of filling and mode of operation, etc., (Wall and Zeiss, 1995; Bareither et al., 2011).

Most landfill settlement models were developed for inorganic soils or peat. Sowers adopted a conventional soil mechanics approach to predict waste settlement. That

Corresponding Author: Entessar Kareem Hussain, Department of Civil Engineering, College of Engineering, University of Al-Qadisiyah, Al Diwaniyah, Iraq, entesar_kareem@yahoo.com 
is the total settlement is determined as the sum of primary and secondary consolidation settlements. From a limited number of data, Sowers showed that the primary and secondary compression indexes, $\mathrm{C}_{\mathrm{c}}$ and $\mathrm{C}_{\mathrm{a}}$ may be correlated to the initial void ratio, $e_{0}$ where $C_{c}=0.15-0.55$ $\mathrm{e}_{0}$ and $\mathrm{C}_{\mathrm{a}}=0.03-0.09 \mathrm{e}_{0}$. These correlations were however, based on measurements up to 15 month. Morris and Woods and Fassett et al. provided additional insights into the use of consolidation theory. The soil mechanics approach as discussed before requires precise determination of waste parameters. Uncertainty associated with material properties renders this approach less attractive for wastes when compared to soils. It is difficult to identify the magnitude of primary consolidation settlement as well as the time taken. Since, the wastes exhibit a highly compressible skeleton, primary and secondary consolidations occur simultaneously.

Furthermore, these models were developed considering the traditional operation of landfill where leachate resulting from degradation process was drown out the entire system (Edil et al., 1990).

Bjarngard and Edgers (1990) applied the same Sowers model with significant modification by subdividing secondary compression into two sub phases. On the other site empirical models were studied extensively to find the suitable model that should be applied in conventional landfills (McDonald, 2018).

In this study, the reasons for the simulation errors of the traditional models are revealed; based on soil mechanics based model, a new time model for total settlement process is proposed. At the same time, the new model may be useful to the design and reutilization of the MSW landfills in both sanitary and bioreactor landfills.

Modified model theory: The proposed model is a adaptation of a soil mechanics model with an important modification based on.

Changing in the densities of multi landfill stratums which produced differed stresses at the mid depth of each layer changing the primary compression and secondary compression indices of waste with time by taking into account the degree of decomposition and change of moisture content on the mentioned indices.

The model proposed consists of three elements at which the settlement component can be generally evaluated and represented by Eq. 1:

$$
\varepsilon_{\mathrm{t}}=\left(\varepsilon_{\mathrm{p}}+\varepsilon_{\mathrm{c}}+\varepsilon_{\mathrm{b}}\right)
$$

Where:

$$
\begin{array}{ll}
\varepsilon_{\mathrm{t}} & =\text { Total strain } \\
\varepsilon_{\mathrm{p}} & =\text { Strain due to applied stress }
\end{array}
$$

$\varepsilon_{\mathrm{p}}$ can be determined using the formulation provided by Burlingame cited in (DeAbreu, 2003), the first element represented the change in the stiffness of waste in relation to the change of density and moisture content associated with the degree of degradation and this is reflected by the change modified coefficient of compression $\left(\mathrm{C}_{\mathrm{c}}{ }^{*}\right)$ which represents the relationship between stress and strain, that change does not stop after a period of time but continues as logarithmic function of time. Equation 2 for each layer of waste $\varepsilon_{\mathrm{p}}$ calculated from Eq. 3:

$$
\begin{gathered}
\mathrm{C}_{\mathrm{c}}=\mathrm{C}_{\mathrm{c}}^{*} * \log \left(\frac{\mathrm{t}_{3}}{\mathrm{t}_{1}}\right) \\
\varepsilon_{\mathrm{p}}=\mathrm{C}_{\mathrm{c}}^{*} * \log \frac{(1 / 2) \gamma_{\mathrm{i}} * \mathrm{H}_{\mathrm{i}}+\sum_{\mathrm{j}=\mathrm{i}+1}^{\mathrm{n}}\left(\gamma_{\mathrm{j}} \mathrm{H}_{\mathrm{j}}\right)}{\left((1 / 2) \gamma_{\mathrm{i}}^{*} \mathrm{H}_{\mathrm{i}}\right)} \log \left(\frac{\mathrm{t}_{3}}{\mathrm{t}_{1}}\right)
\end{gathered}
$$

Where:

$\mathrm{C}_{\mathrm{c}}=$ Compression index

$\mathrm{C}_{\mathrm{c}}{ }^{*}=$ Modified compression index

$\mathrm{n}=$ Number of layer

$\mathrm{H}_{\mathrm{i}}=$ Initial thickness of layer $\mathrm{i}$

$\gamma=$ Unit weight of layer $\mathrm{i}$

$\mathrm{t}_{1}=$ Time for immediate compression completed

$\mathrm{t}_{3}=$ Analysis time

At the early stages of decomposition, the strain can be instantaneous and dependent on the degree of saturation. The creep strain $\left(\varepsilon_{c}\right)$ can be evaluated as equal to Eq. 4:

$$
\varepsilon(t)_{c}=C_{c r} \log \left(\frac{t_{2}}{t_{1}}\right)
$$

Where:

$$
\begin{aligned}
\mathrm{C}_{\mathrm{cr}}= & \text { Creep compression index } \\
\mathrm{t}_{2}= & \text { Time duration for which "creep" compression is } \\
& \text { to be evaluated }
\end{aligned}
$$

As the moisture content increases and the growth of microorganisms increases, the deformation moves to the next stage where it is ruled by the decomposition phase. The organisms are fully functional where biodegradable waste mass are rapidly dehydrated, separated, fermented and metabolized into their final compounds such as methane, carbon dioxide and soluble compounds. This "biological" strain component can be represented as Eq. 5 :

$$
\varepsilon(t)_{b}=C_{\beta} \log \left(\frac{t_{3}}{t_{2}}\right)
$$


(a)

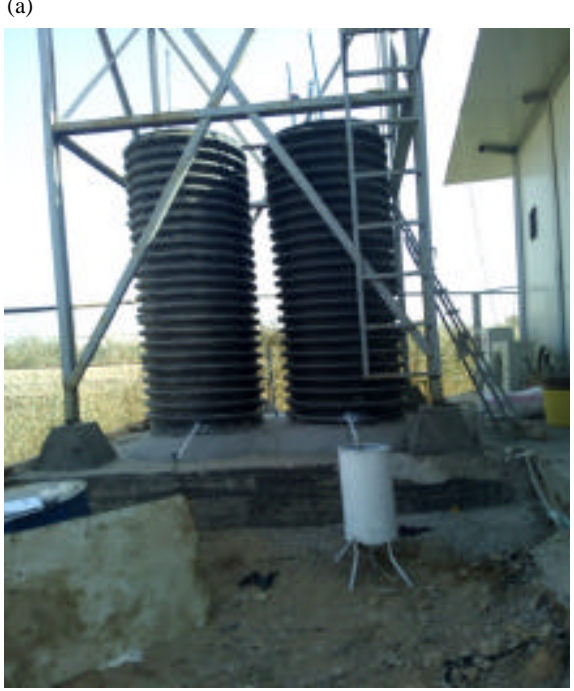

(b)

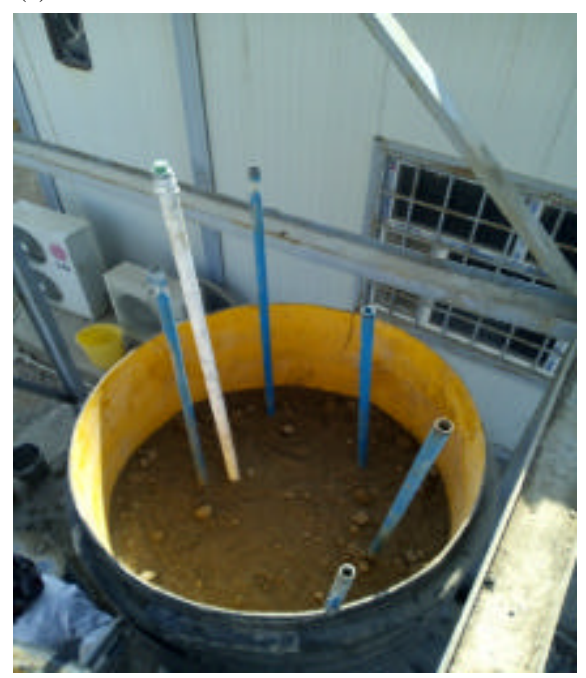

Fig. 1: a, b) Pilot scale lysimeters construction and filling

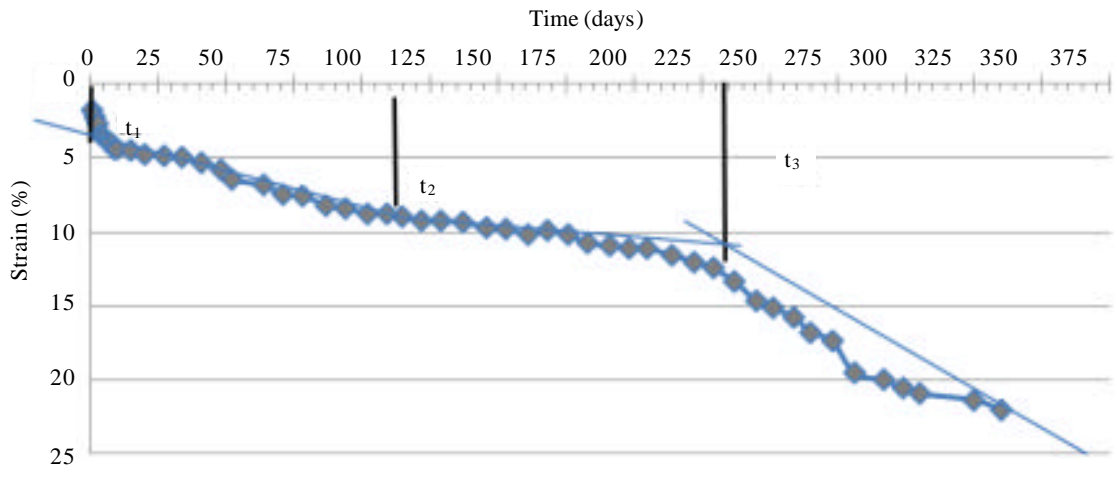

Fig. 2: Long term settlement for sanitary landfill lysimeter

where, $\mathrm{C}_{\beta}$ is biological compression index. In addition to compressibility parameters. The time factors in this model are $t_{1}, t_{2}$ and $t_{3}$. These will be evaluated from a pilot scale lysimeters total settlement curves. Linearization of the three sections of the settlement curve as proposed by Fei and Zekkos (2012) was used, a straight line is fitted to each section of the curve. Intersection points of the three straight lines are defined as $t_{2}$ and $t_{3}$ in Fig. 1 and 2 for sanitary and bioreactor landfills, respectively. The model will be verified based on bioreactor and sanitary landfills data. Finally, the settlement model can be presented by Eq. 6:

$$
\begin{gathered}
\varepsilon_{\mathrm{t}}=\mathrm{C}_{\mathrm{c}}^{*} \log \frac{(1 / 2) \gamma_{\mathrm{i}}^{*} \mathrm{H}_{\mathrm{i}}+\sum_{\mathrm{j}=\mathrm{i}+1}^{\mathrm{n}}\left(\gamma_{\mathrm{j}} \mathrm{H}_{\mathrm{j}}\right)}{\left((1 / 2) \gamma_{\mathrm{i}}^{*} \mathrm{H}_{\mathrm{i}}\right)} \log \left(\frac{\mathrm{t}_{3}}{\mathrm{t}_{1}}\right)+ \\
\mathrm{C}_{\mathrm{cr}} \log \left(\frac{\mathrm{t}_{2}}{\mathrm{t}_{1}}\right)+\mathrm{C}_{\beta} \log \left(\frac{\mathrm{t}_{3}}{\mathrm{t}_{2}}\right)
\end{gathered}
$$

\section{MATERIALS AND METHODS}

Pilot scale lysimeters: Two Pilot Lysimeters (PL) were constructed in the back yard of College of Engineering, University of Al Qadessiya to simulate two types of landfill, one for simulation sanitary landfill (PLS) where the other for simulation bioreactor landfill with leachate recirculation (PLB). Both pilot lysimeters were made of thick multi layer High Density Polyethylene (HDPE) having a cylindrical shape with diameter of $(100 \mathrm{~cm})$ and height of (3 m) with a total volume of $\left(2.35 \mathrm{~m}^{3}\right)$, standing on constructed $\left(4^{*} 4 \mathrm{~m}\right)$ concrete base with $(1 \mathrm{~m})$ height above ground level, the concrete base was necessary for leachate collection as shown in Fig. 1. The waste mass introduced into the pilot lysimeter was divided into five layers, separated by settlement plates to monitor settlement and volume deformation at each layer. All lysimeters were provided with five side ports one in each layer for sampling. 
Table 1: Details of pilot scale lysimeters filling

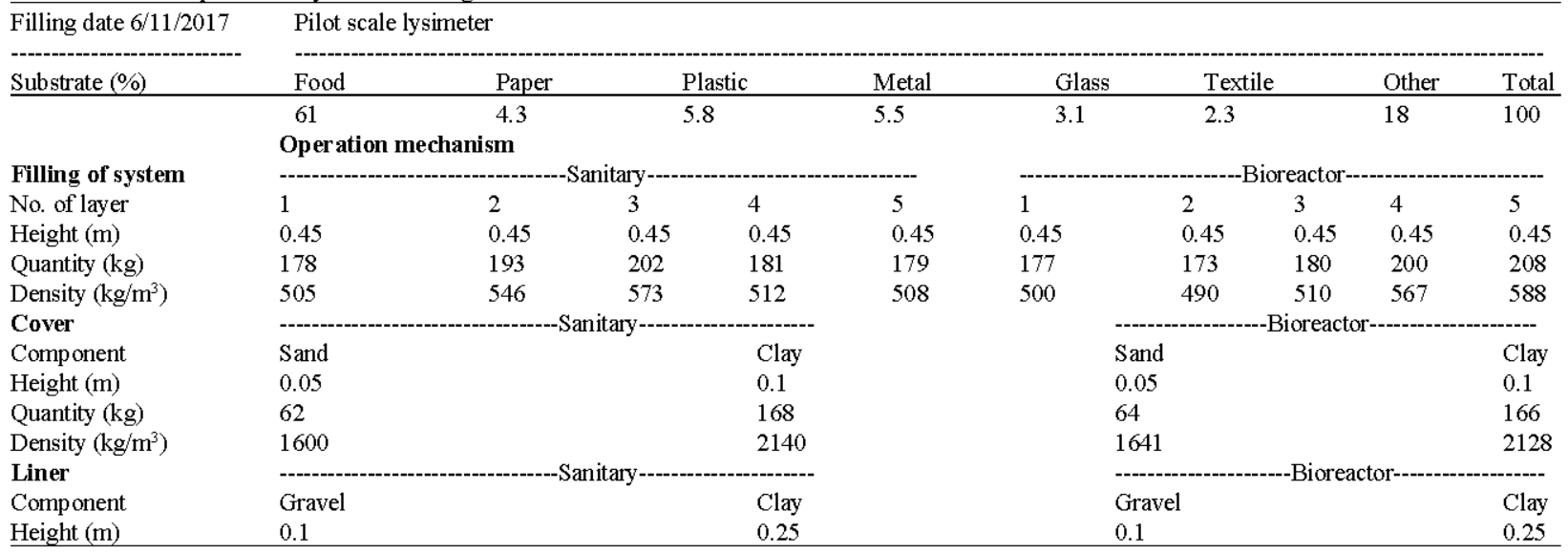

Table 1 shows the physical composition of MSW used in filling the pilot lysimetrs, liner, cover and principal of operation. Layers of compacted, gravel and geotextile sheet were provided at the bottom of lysimeter to prevent a clogging at the outlet by of suspended solids while sand and compacted clay was applied at the top of lysimeters for regular distribution of rainfall and/or leachate recirculated and for protecting the outdoor environment from lysimeter effects such as odour or other pathogen effects.

In the PLS simulator landfill the generated leachate was drained out of the system through a draining pipe contracted at the bottom of it. While leachate generated from PLB simulator landfill was used recirculation through sprinkler constructed at the top of it. The long term effects of leachate drained or recirculation on settlement and volume deformation was performed.

Sample preparation: Refuse samples representing various stages of decomposition were extracted from two pilot-scale lysimeters. The refuse was sampled in Initial adjustment phase (lag phase), acid phase and the accelerated methane production phase as follow.

About $500 \mathrm{~g}$ of MSW samples were drawn from the sampling holes (openings) on the pilot lysimeters side wall. Samples were kept in covered plastic container to be transferred later to the laboratory. After that samples were shredded to the desired size, particles of length equal to no more than half the diameter of oedometer test cell were using high quality grinder (Ririhong Hi-speed multifunctional grinder).

Moisture content and organic content: Moisture content was determined in accordance with the standard procedure ASTM D2216, using Eq. 7 but the samples were dried at a lower constant temperature of $60^{\circ} \mathrm{C}$ (to avoid possible burning of any organic constituents) until the mass remained constant Eq. 7:

$$
\mathrm{W} \%=\frac{\mathrm{w}_{\mathrm{w}}-\mathrm{w}_{\mathrm{d}}}{\mathrm{w}_{\mathrm{w}}} * 100
$$

Where:

$\mathrm{W}_{\mathrm{w}}=$ Wet weight of sample $(\mathrm{g})$

$\mathrm{w}_{\mathrm{d}}=$ Dry weight of sample $(\mathrm{g})$

$\mathrm{w}=$ Water content

The organic content which is a representation of volatile solids in the synthetic MSW was measured as per ASTM D2974 (heated at $750^{\circ} \mathrm{C}$ for $2 \mathrm{~h}$ to achieve constant mass). Degree of Decomposition (DOD) was calculated using Eq. 8 depending on organic content, to express the extent of biodegradation (Andersland et al., 1981 ) Eq. 8:

$$
\mathrm{DOD}=\left(1-\frac{\mathrm{x}_{\mathrm{f}}}{\mathrm{x}_{\mathrm{i}}}\right) *\left(\frac{1}{1-\mathrm{x}_{\mathrm{f}}}\right) * 100
$$

Where:

$$
\begin{array}{ll}
\text { DOD } & =\text { Degree of Decomposition } \\
\mathrm{x}_{\mathrm{i}} & =\text { initial organic fraction } \\
\mathrm{x}_{\mathrm{f}} & =\text { Organic fraction after partial decomposition }
\end{array}
$$

Compressibility test: Confined compressibility testing was carried out in an oedometer to determine compressibility characteristics of samples in different stage of decomposition. Shredded specimens were compacted directly into a $50 \mathrm{~mm}$ diameter by $20 \mathrm{~mm}$ height circular stainless steel ring with a dowel. Tests were performed in conformance with ASTM Test Method (D2435-90). The compacted samples had initial density of $530 \mathrm{~kg} / \mathrm{m}^{3}$. The testing procedure involved subjecting the specimen to a constant vertical stress of $50 \mathrm{kPa}$. Subsequently, the vertical stress was increased to 100 , 200,400 and $800 \mathrm{kPa}$ and compression was monitored for $24 \mathrm{~h}$. Based on the total compression under each normal stress, axial strain versus normal pressure was plotted and primary compression ratio was calculated. Long term 


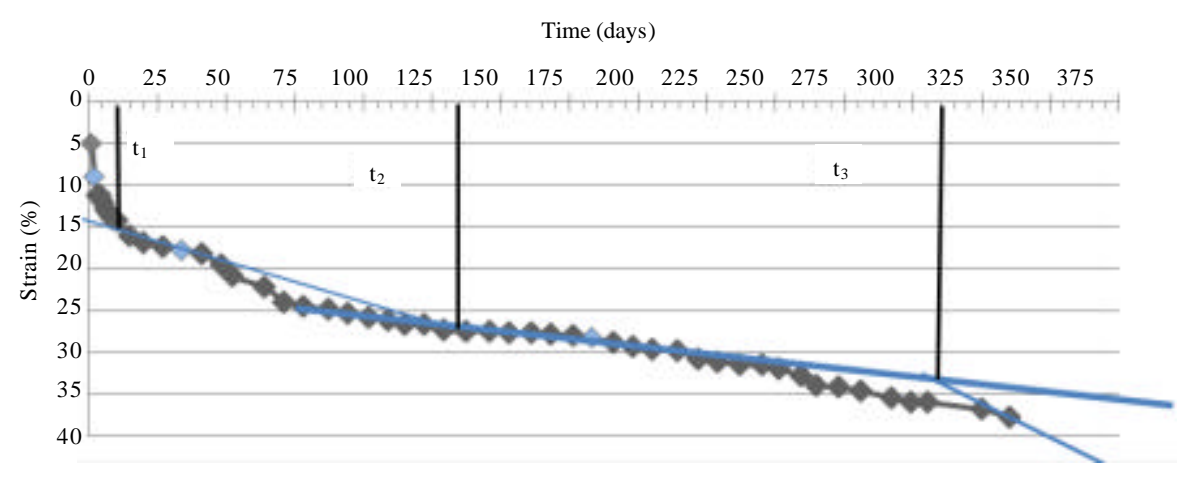

Fig. 3: Long term settlement for bioreactor landfill

compressibility was tested for the second phase sample by following the same procedure until $400 \mathrm{kPa}$ pressure had been reached, vertical pressure was maintained constant and compression was measured with time for 15 days to provide adequate data to assess secondary compression behaviour. Modified compression index $\mathrm{C}_{\mathrm{c}}{ }^{*}$ and modified secondary compression indices $\mathrm{C}_{\mathrm{cr}}$ and $\mathrm{C}_{\hat{\mathrm{a}}}$ were calculated.

Model parameters: The two important sets of parameters were required for the settlement model: the first is the compressibility parameters (primary, creep and biological) and the second is the critical time factor $\left(t_{1}, t_{2}\right.$ and $\left.t_{3}\right)$ that define the change of degradation state.

The time factor required for the model was determined from pilot scale lysimeters total settlement curves. Linearization of the three sections of the settlement curve as proposed by Fei and Zekkos (2012), a straight line is fitted to each section of the curve. Intersection points of the three straight lines are defined as $t_{1}, t_{2}$ and $t_{3}$ in Fig. 2 and 3 for sanitary and bioreactor landfills, respectively.

Time factor for completion of initial compression, $t_{1}$ : Initial compression takes place immediately once the load is applied. The settlement monitoring results showed the initial compression time it takes (7-10 days) in both sanitary and bioreactor simulated landfills

Time factor for creep compression, $\mathbf{t}_{2}$ : After completion of immediate compression, settlement continues due to time dependent physical mechanisms such as particle reorientation and movement, ravelling, delayed compression of deformable particles as a result of stress distribution and potential softening of waste constituents due to the introduction of moisture in the waste mass (Bareither et al., 2011). It takes (120-135) days in both sanitary and bioreactor simulated landfills.
Time factor for biological compression, $\mathbf{t}_{3}$ : Continual presence of moisture, MSW settlement continues, the active biodegradation phase occurs when most microbial species reach their maximum growth rates and thus, a strong microbial community has been established (Bareither et al., 2011). $\mathrm{t}_{3}$ estimated to be continuing to the end of experiment time.

\section{RESULTS AND DISCUSSION}

Water content and degree of decomposition: The water content and degree of decomposition for fresh, first phase, second phase and third phase of sampled refuse presented in Table 2.

From Table 2 it can be noted that the moisture content in PLS decrease with time, opposing with PLB where the moisture content increase with time. While DOD in both simulator was increased with time. The DOD was much higher than those in PLS for the same phases. However, leachate recirculation seems to improve both of DOD and water content in PLB simulator lysimeter. From this standpoint, increase water content can be considered as indicator for enhancing the degree of decomposition.

Compression parameters: The compressibility parameters obtained from oedometer test are presented in Table 3. As seen, the value of primary compression index $\mathrm{C}_{\mathrm{C}}{ }^{*}$ were calculated at different stage of decomposition for sanitary and bioreactor landfills during different times of operation whil evalues for secondary compression index was calculated at an intermediate time of operation when the ' $t$ ' value is 120 day to study the biodegradation effects more clearly. Values of modified primary compression indices $\mathrm{C}_{\mathrm{C}}{ }^{*}$ for sanitary landfill samples were similar to the trend bioreactor landfill samples, both increases with time. Generally, the reported modified primary compression indices $\mathrm{C}_{\mathrm{C}}{ }^{*}$ lie in the range of $0.15-0.3$ and are much close with the $\mathrm{C}_{\mathrm{C}}{ }^{*}$ values range of $0.17-0.36$ reported by 
J. Eng. Applied Sci., 14 (Special Issue 4): 7305-7312, 2019

\begin{tabular}{|c|c|c|c|c|c|}
\hline Day of sampling & Phases & Principle of operation & Water content (\%) & Loss of ignition (\%) & Degree of decomposition (\%) \\
\hline \multirow[t]{2}{*}{1} & Fresh & Sanitary & 68 & 72 & 0 \\
\hline & & Bioreactor & 66 & 74 & 0 \\
\hline \multirow[t]{2}{*}{34} & First phase & Sanitary & 66 & 71 & 5 \\
\hline & & Bioreactor & 62 & 73.2 & 4 \\
\hline \multirow[t]{2}{*}{120} & Second phase & Sanitary & 53 & 58 & 46 \\
\hline & & Bioreactor & 61 & 55 & 57 \\
\hline \multirow{2}{*}{240} & Third phase & Sanitary & 32 & 44 & 69 \\
\hline & & Bioreactor & 67 & 36 & 80 \\
\hline
\end{tabular}

\begin{tabular}{|c|c|c|c|c|c|}
\hline $\begin{array}{l}\text { Day of } \\
\text { sampling }\end{array}$ & phases & $\begin{array}{l}\text { Principle of } \\
\text { operation }\end{array}$ & $\mathrm{C}_{C}{ }^{*}$ & $\mathrm{C}_{c r}$ & $\mathrm{C}_{\beta}$ \\
\hline \multirow[t]{2}{*}{1} & \multirow[t]{2}{*}{ Fresh } & Sanitary & 0.15 & - & - \\
\hline & & Bioreactor & 0.16 & - & - \\
\hline \multirow[t]{2}{*}{34} & \multirow[t]{2}{*}{ First phase, } & Sanitary & 0.18 & - & - \\
\hline & & Bioreactor & 0.21 & - & - \\
\hline \multirow[t]{2}{*}{120} & \multirow[t]{2}{*}{ Second phase } & Sanitary & 0.20 & 0.033 & 0.07 \\
\hline & & Bioreactor & 0.23 & 0.035 & 0.11 \\
\hline \multirow[t]{2}{*}{240} & \multirow[t]{2}{*}{ Third phase } & Sanitary & 0.24 & - & - \\
\hline & & Bioreactor & 0.30 & - & - \\
\hline
\end{tabular}

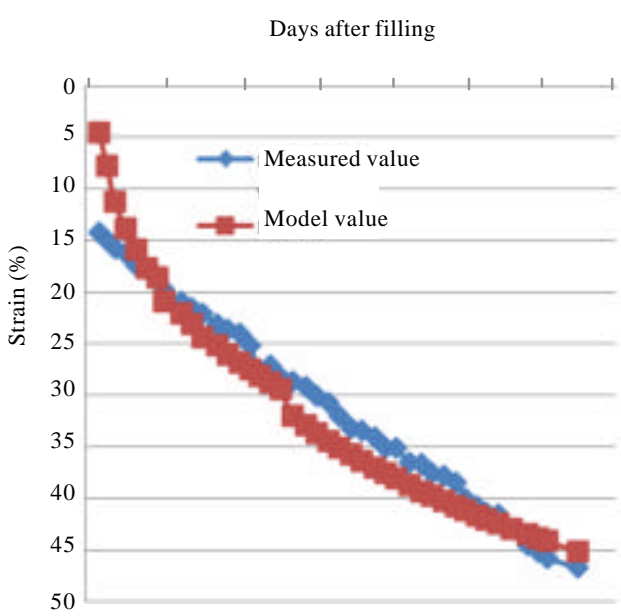

Fig. 4: Measured and model value for layer 1 in bioreactor landfill

Qian et al. (2002). In this study, the value of compressibility indices for bioreactor landfill were slightly higher than those of sanitary landfill with a general trend of increasing compressibility indices with increase in degradation. The more thoroughly decomposed samples (higher DOD) had a weakened structural matrix, leading to an increase in initial settlement under the same applied stress. Overall these findings are in accordance with findings reported by Hossain and Gabr (2005), Reddy et al. (2015) and Wall and Zeiss (1995) but contradicts the correlation found by Reddy et al. (2011) for synthetic MSW which showed decreasing compression ratio with increase in degradation. There are wide range in the published values of these parameters, this wide range is could be attributed to the large variations in compositions of wastes involved, the various ages of the landfills and the stresses to which wastes have been subjected. In general, the results of this study are comparable with other published values (Fig. 4-8).

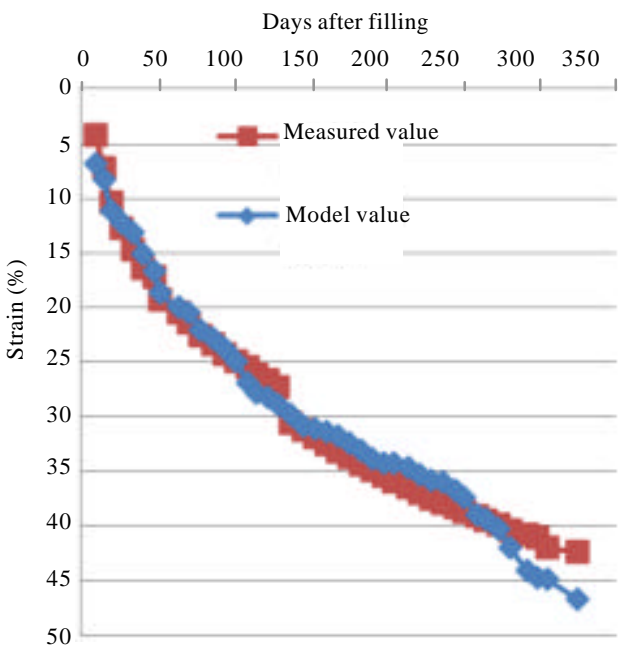

Fig. 5: Measured and model value for layer 2 in bioreactor landfill

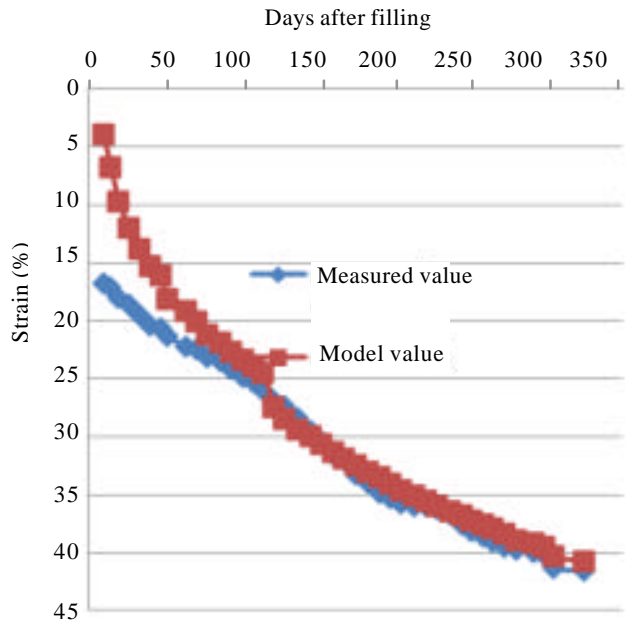

Fig. 6: Measured and model value for layer 1 in sanitary landfill

Model validation and result of model prediction: The developed model validation is an important part of the model development process. Utilizing the model, the predicted MSW settlement was compared with the observed field settlement from different layers in pilot sanitary and bioreactor landfills. The settlement data have 


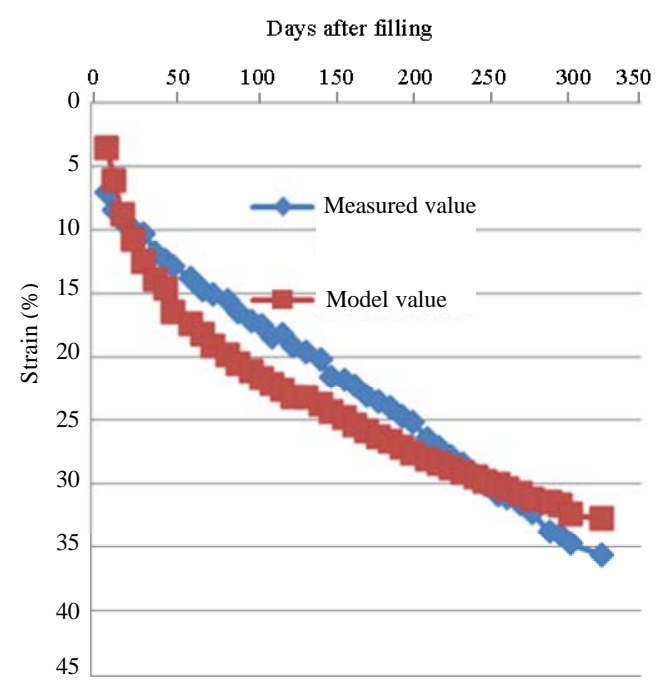

Fig. 7: Measured and model value for layer 2 in sanitary landfill

been collected from monitoring settlement in sanitary and bioreactor lysimeters during 335 day. The model parameter $t_{1}$ and $t_{2}$ in sanitary landfill had been taken as 7 and 120 days, respectively, while in bioreactor landfill their values were 10 and 135 day. Using these time factors and compressibility parameters obtained from experimental results, the computed settlement had been compared with the observed settlement data in Fig. 4-8 for bioreactor and sanitary landfills layers, respectively. The predicted results matched quite well with the measured field data. With a very good agreement between the measured and model data, coefficient of correlation close to 1.0.

\section{CONCLUSION}

Most settlement models were applied to solid waste developed for inorganic soils or peat. It is important to mentioned that these models were not developed considering the all the factors effect on settlement. Besides these model were conducted the settlement in conventional landfill only (sanitary landfills). In case of bioreactor landfills, waste settlement will include creep as well as the biological components due to the accelerated degradability of waste as leachate is recycled. A settlement model was developed to incorporate the changes in waste properties that take place during the decomposition of the waste matrix. Work in this study was utilized data from laboratory oedometer tests to illustrate compressibility parameters for refuse at different degrees of decomposition and to define the time factors required for modelling. Based on the experimental results in this study it can be concluded that:

Primary compression ratio values varied from $0.15-0.3$ and found to be within the range of previous published studies. The primary compression ratio shows a slightly increasing trend with degree of degradation and moisture content which needs further investigation by testing the samples with the same composition in a large-scale setup.

The Creep index $\left(\mathrm{C}_{\mathrm{rc}}\right)$ had been estimated as 0.03 for both sanitary and bioreactor landfill samples. The magnitude of the biological indices was yielded the highest values $\left(C_{\beta}=0.11\right)$ in bioreactor landfill were samples actively decomposing. For the model prediction, $\mathrm{C}_{\mathrm{rc}}$ and $\mathrm{C}_{\beta}$ have been taken as 0.03 and 0.07 for sanitary landfill and 0.03 and 0.07 for bioreactor landfill, respectively.

The time factors $\left(t_{1}, t_{2}\right.$, and $\left.t_{3}\right)$ vary depend on the mode of operation. Time factor $t_{2}$ is the time when accelerated creep settlement. The time factor $t_{2}$ as observed in most of the field studies can be considered as between 120 and 135 days. More work is needed to define the time factors, especially consideration for time factor $t_{2}$.

The settlement prediction matches well with the settlement measured data, the model settlement prediction considers all the aspects of biological decomposition, creep and matrix stiffness change as decomposition takes place with time.

\section{REFERENCES}

Andersland, O.B., A.S. Khattak and A.W.N. Al-Khafaji, 1981. Effect of Organic Material on Soil Shear Strength. In: Laboratory Shear Strength of Soil, Yong, R.N. (Ed.). ASTM International, Pennsylvania, USA., pp: 226-242.

Babu, G.L.S., K.R. Reddy, S.K. Chouskey and H.S. Kulkarni, 2009. Prediction of long-term municipal solid waste landfill settlement using constitutive model. Pract. Period. Hazard. Toxic Radioactive Waste Manage., 14: 139-150.

Bareither, C.A., C.H. Benson, T.B. Edil and M.A. Barlaz, 2011. Abiotic and biotic compression of municipal solid waste. J. Geotech. Geoenviron. Eng., 138: $877-888$

Bjarngard, A. and L. Edgers, 1990. Settlement of municipal solid waste landfills. Annu. Madison Waste Conf., 1: 192-205.

DeAbreu, R., 2003. Facultative bioreactor landfill: An environmental and geotechnical study. Ph.D Thesis, The University of New Orleans, New Orleans, Louisiana.

Edil, T.B., V.J. Ranguette and W.W. Wuellner, 1990. Settlement of Municipal Refuse. In: Geotechnics of Waste Fills: Theory and Practice, Landva, A. and G.D. Knowles (Eds.). ASTM International, Pennsylvania, USA., pp: 225-239. 
El-Fadel, M. and R. Khoury, 2000. Modeling settlement in MSW landfills: A critical review. Crit. Rev. Environ. Sci. Technol., 30: 327-361.

Fei, X. and D. Zekkos, 2012. Factors influencing long-term settlement of municipal solid waste in laboratory bioreactor landfill simulators. J. Hazard. Toxic Radioactive Waste, 17: 259-271.

Grisolia, M., 1996. Geotechnical characterization of municipal solid waste: Choice of dezaign. Environ. Geotech., 1: 641-646.

Hossain, M.S. and M.A. Gabr, 2005. Prediction of Municipal Solid Waste Landfill Settlement with Leachate Recirculation. In: Waste Containment and Remediation, Alshawabkeh, A., C.H. Benson, P.J. Culligan, J.C. Evans and B.A. Gross et al., (Eds.). ASCE, Virginia, USA., ISBN:9780784407899, pp: 1-14.

Ling, H.I., D. Leshchinsky, Y. Mohri and T. Kawabata, 1998. Estimation of municipal solid waste landfill settlement. J. Geotech. Geoenviron. Eng., 124: 21-28.

McDonald, R.P., 2018. Modelling the mechanical behaviour of municipal solid waste for an engineered landfill using viscoelasticity and other established concepts. Ph.D Thesis, Carleton University, Ottawa, Canada.
Qian, X., R.M. Koerner and D.H. Gray, 2002. Geotechnical Aspects of Landfill Design and Construction. Prentice Hall, Upper Saddle River, New Jersey, USA., ISBN:9780130125064, Pages: 717.

Reddy, K.R., H. Hettiarachchi, J. Gangathulasi and J.E. Bogner, 2011. Geotechnical properties of municipal solid waste at different phases of biodegradation. Waste Manage., 31: 2275-2286.

Reddy, K.R., H. Hettiarachchi, R.K. Giri and J. Gangathulasi, 2015. Effects of degradation on geotechnical properties of municipal solid waste from Orchard Hills Landfill, USA. Intl. J. Geosynthetics Ground Eng., 1: 1-14.

Wall, D.K. and C. Zeiss, 1995. Municipal landfill biodegradation and settlement. J. Environ. Eng., 121: 214-224.

Zhang, S. and W. Wang, 2008. New model for total settlement process of municipal solid waste landfill. Proceedings of the 2008 International Workshop on Modelling, Simulation and Optimization, December 27-28, 2008, IEEE, Hong Kong, China, ISBN:978-0-7695-3484-8, pp: 151-154. 